\title{
The influence of the location of emergency exits over the distance to be covered to the exit of an environment
}

\author{
A influência da localização das saídas de emergência \\ sobre a distância a ser percorrida até a saída de um \\ ambiente
}

\section{Henrique Costa Braga \\ Gray Farias Moita \\ Paulo Eduardo Maciel de Almeida}

\section{I}

Abstract

$\mathrm{n}$ a building environment design, the positioning, size and quantity of the exits are fundamental aspects and have an intense relationship with the fire safety of the environments. An aspect that is influenced by these parameters is the average distance to be covered by occupants to the nearest exits during an escape in an emergency situation. The average distance could be used as a complementary measure of the safety of an environment (a lower average distance value indicates a probable faster evacuation rate). Thus, a pathfinder type algorithm to determine the value of the average distances to be covered to the nearest exit during an escape of an environment was detailed and implemented. Computational experiments were performed and the relationship between positioning, quantity and size of the exits and the value of the average distances were studied. The main conclusion was the importance of keeping the exits as far away from each other as possible in a given environment, so that a small distance to be covered could be obtained.

${ }^{1}$ Henrique Costa Braga ${ }^{1}$ Centro Federal de Educaçãa Tecnológica de Minas Gerais Belo Horizonte - MG - Brasil

${ }^{2}$ Gray Farias Moita ${ }^{2}$ Centro Federal de Educação Tecnológica de Minas Gerais Belo Horizonte - MG - Brasil

${ }_{3}^{3}$ Paulo Eduardo Maciel de Almeida ${ }^{3}$ Centro Federal de Educação Tecnológica de Minas Gerais Belo Horizonte - MG - Brasil

Recebido em 14/05/18 Aceito em 21/07/18
Keywords: Evacuation. Fire. Escape time. Safety index.

\section{Resumo}

No projeto de um ambiente construído, o posicionamento, tamanho e quantidade de saídas são aspectos fundamentais e têm uma relação direta com a sua segurança contra incêndio. Um aspecto que é influenciado por esses parâmetros é a distância média a ser coberta pelos ocupantes para as saídas mais próximas durante uma fuga em uma situação de emergência. A distância média poderia ser usada como medida complementar de segurança de um ambiente (um valor de distância médio mais baixo indica uma taxa de evacuação provável mais rápida). Assim, um algoritmo do tipo de busca e exploração pode ser usado para se determinar o valor das distâncias médias a serem percorridas até a saída mais próxima durante o abandono de um ambiente foi apresentado. Foram realizados experimentos computacionais e se estudou a relação entre posicionamento, quantidade e tamanho das saídas e o valor das distâncias médias. A principal conclusão foi da importância de manter as saídas tão longe entre si quanto possível, reduzindo em muito a distância média a ser percorrida.

Palavras-chave: Saídas de emergência. Incêndio. Tempo de escape. Índice de segurança. 


\section{Introduction}

Considering the computational models and the software currently available (PECHELANO; ALLBECK; BADLER, 2008; RONCHI, NILSSON, 2013), the influence of the emergency exits (their positioning, quantity and width) on the safety of an environment can be previously analysed during the engineering or architectonical design process. Several optimization techniques can also be directly used to determine the best configuration or route (LUJAK, OSSOWSKI, 2017; XIE et al., 2018). However, sometimes these parameters are not fully understood and considered during the design phase. The reason for this can be because the technology available might not be used (or, at least, adequately used), or is only used to achieve the minimum acceptable legal considerations. Therefore, an analytical (and critical) discussion about the influence of these aspects on the environment safety is of great value, especially for environments such as nightclubs, which are historically sensitive in terms of safety, even the small ones (DUVAL, 2006).

In 2013, Brazil was the scenario of a great tragedy in Boate Kiss, a night club in the city of Santa Maria, state of Rio Grande do Sul, where 242 people were killed. As it usually happens in these tragedies, there were many reasons that contributed to the disaster and its dimension. One of these points is the need of review, or further discussions, of the applicable legal codes (SILVA FILHO et al., 2013; BRAGA, MOITA, 2017). With regard to the existing codes, a point that should be brought into discussion is the determination of positioning, size and quantities of exits that are necessary to ensure "safety" in an environment such as this. According to Brazilian Standard (ABNT, 2001), Boate Kiss needed at least two distinct emergency exits. In fact, there were two exits, however they were located side-by-side, with almost no separation between them (Figure 1).

ABNT (2001) brings no specific restrictions about the exits' positioning. The authorities (in this case, the Fire Brigade of the State of Rio Grande do Sul CBMRS) were aware of the situation but they considered it as an acceptable condition. This happened probably due to the lack of details in the standards, to the absence of other parameters, to the prescriptive characteristic of most of the Brazilian fire fighting legal codes (TAVARES, 2009; CLARET, MATTEDI, 2011) and to the small amount of specific critical literature about it.

The human movement in an escape situation is a very sophisticated phenomenon (KOBES et al., 2010). Therefore, there are a lot of important factors to be considered in order to analyse the safety conditions of a specific environment. As examples of factors that influence the safety conditions in emergency situation, one could list: perception and reaction time (DORAZIO et al., 2015), nonproportional use of the exits (LOW, 2000), selforganization (GOLDSTONE, ROBERTS, 2006), evacuation manner (organised or competitive) and social interactions (PAN et al., 2007), visual information between people (MOUSSAÏD; HELBING; THERAULAZ, 2011), door capacity (DAAMEN, HOOGENDOORN, 2012), people with mobility impairments (KULIGOWSKI et al., 2015), communication and memory (XUE et al., 2016), among many others.

\section{Figure 1 - Main facade of Boate Kiss with the side-by-side emergency exits}



Source: adapted from Google Maps of “R. dos Andradas, 1925, Santa Maria, RS, Brasil” (Street View - oct. 2012). 
However, despite the importance of the aforementioned aspects, there is a point that is not yet satisfactorily treated in the literature, or in the applicable codes, and which can be an interesting additional parameter to help the determination of the security level of an environment such as Boate Kiss: the average distance to be covered by the occupants to the nearest exit. A shorter average distance to be crossed can significantly contribute to a safer environment due to the shorter time (and, consequently, less efforts) required to complete the escape.

Obviously, the influences of all conditions are fundamental, and, based on the configurations, the importance of the average distance can even be misconceived, but this is a complementary aspect that should be taken into consideration afterwards. The maximum distance is obviously an important point (TAVARES, 2010) but, depending on the geometry of the environment, it can hide the truth about the safety concerns, in a way that the average distance appears to be a promising paired parameter. In spite of the relevance of this subject to nightclub-type environments, other environments also can benefit from the study of the maximum and average distances to reache the exit (BOSINA; MEEDER; WEIDMANN, 2017).

The average distance to the nearest exits, as proposed in this work, is strongly dependent on the geometry of the environment and on the positioning of the exits. Thus, the aim of this work is to propose a method to calculate the average distance to be covered by occupants to reach the nearest exits for any environment, to show its importance as a complementary measure of safety and to analyse the influence of the positioning, the size and the number of exits in the escape route. Moreover, it should be able to yield more information about the relevance of the exits' configuration and their locations.

\section{Methodology}

Is important to note that, for the purpose of this work, only the width of the exit discharge doors was considered, disregarding all other elements of the emergency exit. However, the emergency exit always must be considered in the project as a set of items, also including the access or horizontal exit routes, stairs or ramps and the exits themselves, as well as the discharge doors. All these items are individually defined in NBR 9077 (ABNT, 2001; BRAGA; MOITA, 2017).

The distance to be covered by one person to the nearest exit is obviously related to the position of this person in the environment, amongst other factors. To eliminate the influence of the initial position of the person, an average distance is considered for each environment, which is the average distance to the nearest exit considering all possible positions to be occupied by only one person. Therefore, each environment and exit configuration have only one exact value (the average distance to the exits), independently of the population size and their initial locations.

To determine the average distance to the exits of a specific environment, the first step is to discretise the environment in a two-dimensional matrix, named the Environment Matrix (EM). Each element of this matrix represents a part of environment, whose resolution is proportional to the overall dimensions of the environment. All the environment elements (walls, internal obstructions and exits) must be an exact multiple of this resolution. After the environment discretisation, it is necessary to run a pathfinder type algorithm within the EM matrix to calculate the possible distances.

There are several examples of these algorithms, such as A-star or Dijkstra (SOLTANI et al., 2002), however they are not suitable for the current problem. One possible solution is to use algorithms based on the search over the first neighbourhood of each matrix element, according to Von Neumann or Moore criteria (ROGSCH, 2016). These are algorithms appropriate for this problem, but, depending on the geometry of the environment, they can introduce significant errors (BRAGA; MOITA; ALMEIDA, 2016a). Hence, the option chosen here was to use the VS search algorithm, because, in addition to being also suitable for this type of problem, it produces smaller deviations from the ideal solutions and excellent performance (BRAGA; MOITA; ALMEIDA, 2016b).

\section{The VS search algorithm}

The VS algorithm is a type of breadth-first search algorithm (starting the search at the exits, and from there going through the whole environment). During the search, a distance map and a reference map (THOMPSON; MARCHANT, 1995; BRAGA; MOITA; ALMEIDA, 2017) are created concomitantly. The reference map is a kind of route map, with no (or few) sudden changes in the indicated direction to the exit. This reference map is built based upon the principle of visibility (TOMPSON, 1977). Braga, Moita and Almeida (2016b) describes in details the VS algorithm.

As an example, consider the environment represented in Figure 2. Initially, all positions within the environment, that is not occupied by walls or exits, have values " 0 " in the respective elements of the EM matrix; the walls have values “1 ”; the exits have values “-2”; and any eventual 
external parts of environment have value “-3”. Afterwards, every element (row, column) that represents an exit is placed into a new line matrix called Search Matrix (SM). The positioning sequence of the exit elements in the SM matrix is not relevant. Figure 3 shows the initial EM and SM matrices for the environment of Figure 2.

Considering the VS algorithm application, from the initial targets (indicated in SM matrix) to the entire inner part of the environment (cells with value " 0 " in EM matrix), the final EM matrix (or distance map) was obtained, including, in each cell, the distance of the element to the nearest exit and the reference map. The Figure 4 shows the distance map and the reference map for the environment of Figure 2.

The VS search algorithm works without human intervention (it runs automatically) for any environment design (internal and external) and any exits positioning. The computational implementation of the VS algorithm was made in Python and is part of Path module of program Fuga (BRAGA; MOITA; ALMEIDA, 2016b).

Figure 2 - Representation of an environment (rectangular format with two exits) in perspective view and its respective top projection (no scale)

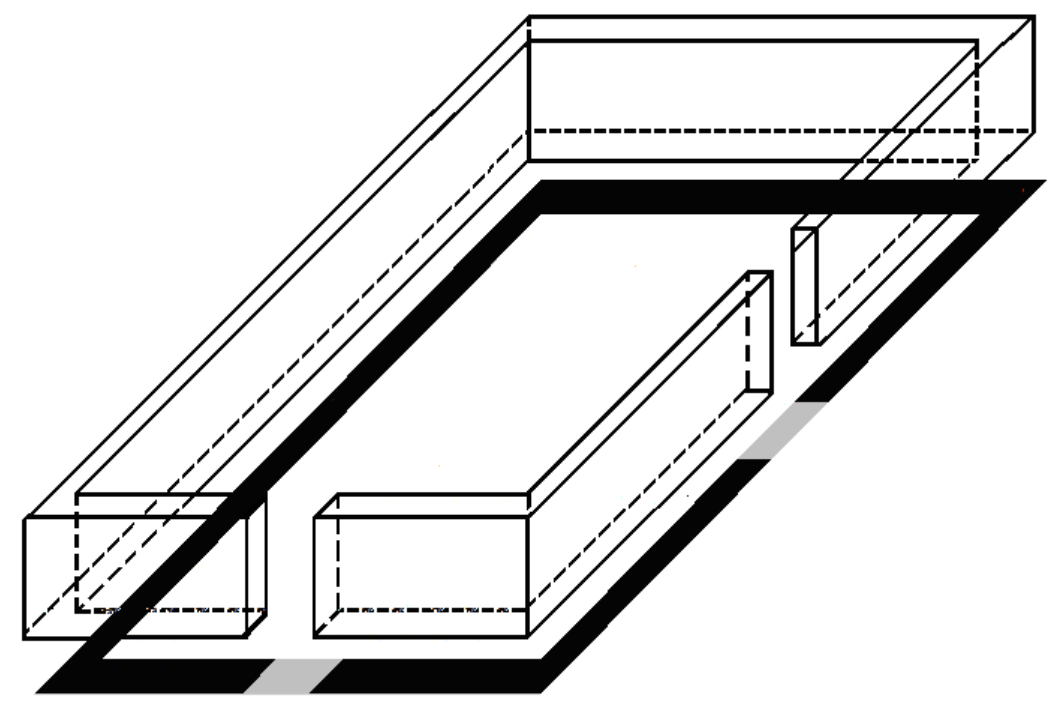

Figure 3 - Initial EM matrix and initial SM matrix for the environment of Figure 2

\section{Columns}



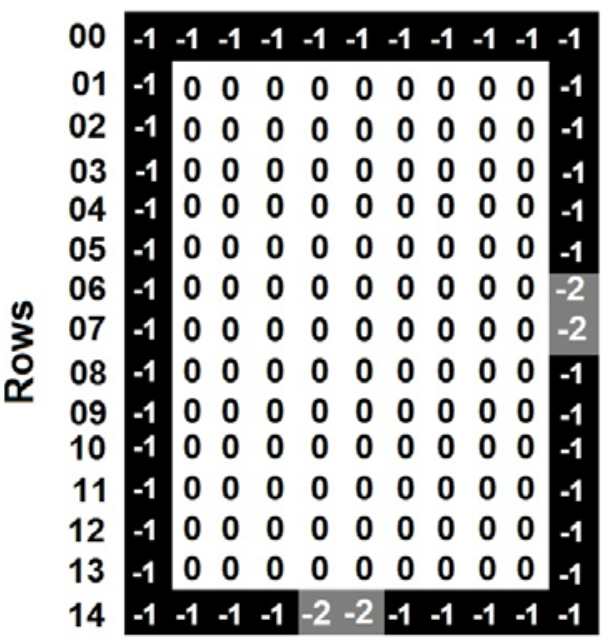

\section{EM matrix}



SM matrix 
Figure 4 - Stylised distance map (a) and stylised reference map (b), both for the environment of Figure

2



(a)

\section{The average distance to the exits}

With the final EM matrix (distance map) fully determined, the average distance to the nearest exits for a specific environment can be obtained numerically by Eq. (1), the point distance by Eq. (2) and the maximum distance by Eq. (3), as below:

$d_{a}=r \times\left(\left.\frac{\sum_{l_{i}=1}^{n_{l}} \sum_{c_{j}=1}^{n_{c}} d_{e}}{\left(n_{l} \times n_{c}\right)-n_{0}}\right|_{\Theta}\right)$

Eq. 1

$d_{p}=r \times d_{e}$

Eq. 2

$d_{m}=r \times \max \left\{d_{e}\right\}$

Eq. 3

Where:

$d_{a}=$ average distance to the nearest exits of the environment;

$d_{e}=$ specific distance in number of elements to the nearest exits of the environment for that position $\left(d_{e}=E M\left(l_{i}, C_{j}\right)\right)$;

$E M\left(l_{i}, C_{j}\right)=$ value of $\mathbf{E M}$ in the coordinates $l_{i}, C_{j}$;

$n_{l}=$ number of rows of EM;

$n_{c}=$ number of columns of $\mathbf{E M}$;



(b)

$n_{0}=$ total number of elements of EM belonging to the walls, exits or external to the environment;

$l_{i}=$ row $i$ of $\mathbf{E M}$;

$c_{j}=$ column $j$ of $\mathbf{E M}$;

$r=$ resolution of $\mathbf{E M}$;

$\Theta=$ specific configuration (design, positioning, size, quantity) of the exits of the environment.

$d_{p}=$ point distance between a specific point of environment and the nearest exits of the environment; and

$d_{m}=$ maximum distance to the nearest exits of the environment; it is the largest $d_{p}$ value found considering all elements of the EM matrix.

\section{Experimental conditions}

Except where explicitly stated, the resolution adopted was $r=5 \mathrm{~cm}$ in all computational experiments of this work. The walls were $10 \mathrm{~cm}$ thick. There was no internal subdivision or walls and just one floor was considered. The experiments were performed:

(a) in circular environments, with external diameter of 20 and $40 \mathrm{~m}$;

(b) in square environments, with external dimensions of 10 and $25 \mathrm{~m}$; and 
(c) in one rectangular environment, with external lengths of 10 and $30 \mathrm{~m}$.

The exits were always placed on the walls. Thus, for circular environments, the size of the exits was related to the size of the respective circumference arch.

The first set of experiments was performed in the circular environments. Experiments were conducted (considering exits of $1 \mathrm{~m}$ ) with $1,2,4,8$, 12 and 20 exits, and did not consider any inner walls. Likewise, experiments were carried out on the same circular environments considering 1 or 2 exits, with widths of 1, 2, 4, 8, 12, 20 and 30 m each (when possible). In all cases, the exits - whenever there was more than one - they were equally distributed along the walls.

The second set of experiments was done in the square and rectangular environments. Experiments were conducted considering 1,2 or 4 exits with sizes of 1, 2, 4 and $8 \mathrm{~m}$ each, positioned at the centre of the side (each one in a different side). Experiments were also conducted considering no internal walls, and, for the experiments with 2 exits, they were positioned at the opposite sides.

Additionally, and also for the square and rectangular environments, experiments were done for several exits of $1 \mathrm{~m}$-size positioned only in one side. Two, four, six and eight exits, equally distributed along this side, were considered.
Finally, experiments were executed in these environments, considering just one exit of 1, 2, 4 and $8 \mathrm{~m}$, positioned at the corner of one side, and also at the mid-position between the corner and the centre of the side. In all cases, the larger side was always considered for the rectangular environment.

\section{Results and discussion}

Figure 5 shows a colourful representation for a map of the $d_{p}$ evolution to the nearest exits for one square environment. The light blue surrounding the maps represents the area outside of the environments, the orange lines in the walls are the exits and the internal colours represent the values of $d_{p}$, where each track represents a distance of $1 \mathrm{~m}$ from the nearest exit. To facilitate the understanding, in Figure 5 identifications of some value of $d_{p}$ in the transitions coloured lines were added. Figure 6 shows similar graphics, but for two circular environments and one rectangular.

Intuitively, a simple visual comparison between Figures $5 \mathrm{a}$ and $5 \mathrm{~b}$, or between Figures $6 \mathrm{a}$ and $6 \mathrm{~b}$, shows the large reduction in the maximum $d_{p}$ values caused by the extra exits located away from another one. Yet, from Figures 5 and 6 it can be seen that the value of $d_{p}$ increases in lines parallel to the exit in the region of its front, and in semi-circles on its sides.

Figure 5 - Map of $d_{p}$ for the square environment with $10 \mathrm{~m}$ side: (a) with 1 exit of $1 \mathrm{~m}$ width (in orange, at bottom centre), and (b) with 4 exits with $1 \mathrm{~m}$ width each (in orange, at each side centre). The respective $d_{p}$ value in [m] are indicated in the transition coloured lines

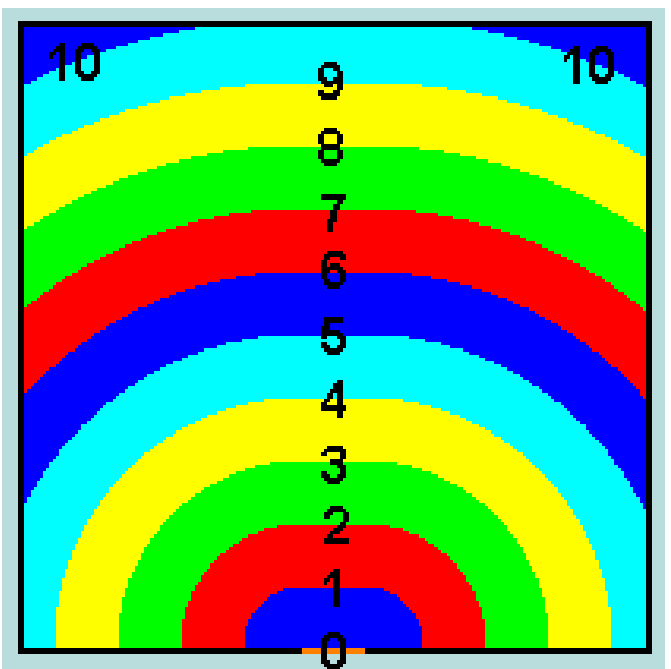

(a)



(b) 
Figure 6 - Map of $d_{p}$ (exits in orange) for a circular environment with a $20 \mathrm{~m}$ diameter (no scale) in (a) with 1 exit of $1 \mathrm{~m}$ of width (at bottom), and in (b) with 4 equidistant exits of $1 \mathrm{~m}$ of width each, and (c) for a rectangular environment $(10 \mathrm{~m} \times 30 \mathrm{~m})$ with one exit of $1 \mathrm{~m}$ in the corner of the one bigger side

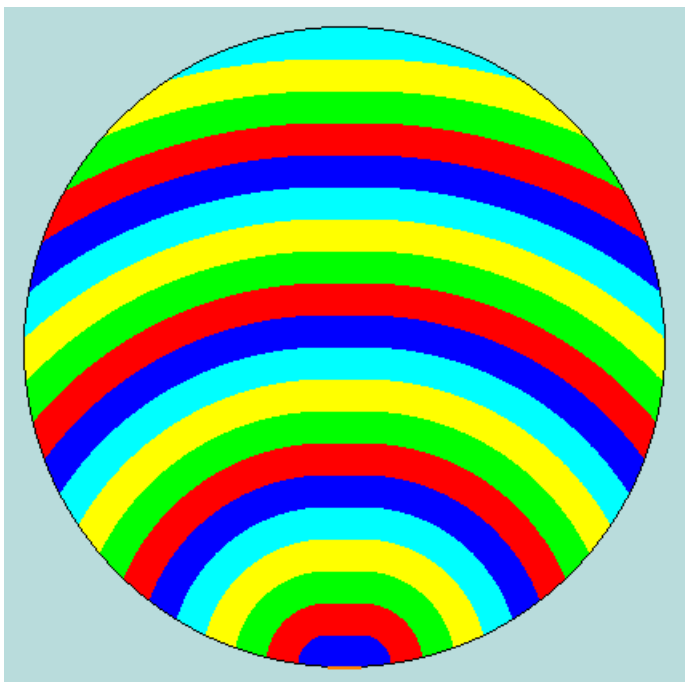

(a)



(b)



(c)

Figure 7 shows the values of $d_{a}$ for the circular environments. Figure $7 \mathrm{a}$ presents the results considering multiples equidistant $1 \mathrm{~m}$ exits and Figure $7 \mathrm{~b}$ presents the results considering just 1 or 2 exits of several different sizes.

A comparison between Figures 7a and 7b shows the relevance of the positioning of the exits with respect to the value of $d_{a}$. For both circular environments, when a $1 \mathrm{~m}$-wide exit is doubled but placed side-byside, the $d_{a}$ value is reduced by only about $2 \%$; however, keeping one $1 \mathrm{~m}$-wide exit in the middle of one side and locating the other one at the opposite side of environment, the value of $d_{a}$ is reduced by around 35\%.

This is a very compelling difference in favour of the increase of the distant between exits. Consequently, in order to achieve the same effect in the value of $d_{a}$ with just two $1 \mathrm{~m}$-wide exits positioned in opposite sides, it would be necessary one unique exit of about $15 \mathrm{~m}$ and $25 \mathrm{~m}$ for the circular environments of diameters of $20 \mathrm{~m}$ and $40 \mathrm{~m}$, respectively.
In Figure 7a (multiple equidistant exits), increasing the number of exits from 2 to 4 , the decrease in the value of $d_{a}$ is still high, but the reduction rate becomes lower, up to a point (approximately around 8 exits) where the reduction rate stabilises and the value of $d_{a}$ becomes close to the lowest possible $d_{a}$. This also shows the relevance of the positioning: with only about 8 equally distributed exits of $1 \mathrm{~m}$ each, one can obtain almost the same effect in $d_{a}$ that would be obtained with no external walls at all. In Figure $7 b$, on the other side, the reduction in the value of $d_{a}$ is approximately linear with the increase of the width of one unique exit or even with just two exits.

Figures 8, 9 and 10 show the results of the evolution of $d_{p}$ for the square and the rectangular environments. Figure 8 presents the results for 1, 2 or 4 exits of sizes of 1, 2, 4 and $8 \mathrm{~m}$ each, positioned at centre of the side (in (a) for the square of $10 \mathrm{~m}$ side, in (b) for the square of $25 \mathrm{~m}$ side, and in (c) for the rectangular environment). 
Figure 7 - Values of $d_{a}$ for the circular environments (diameters of 20 and $40 \mathrm{~m}$ ): (a) considering multiples equidistant $1 \mathrm{~m}$ exits, and (b) considering just 1 or 2 equidistant exits with several widths



(a)

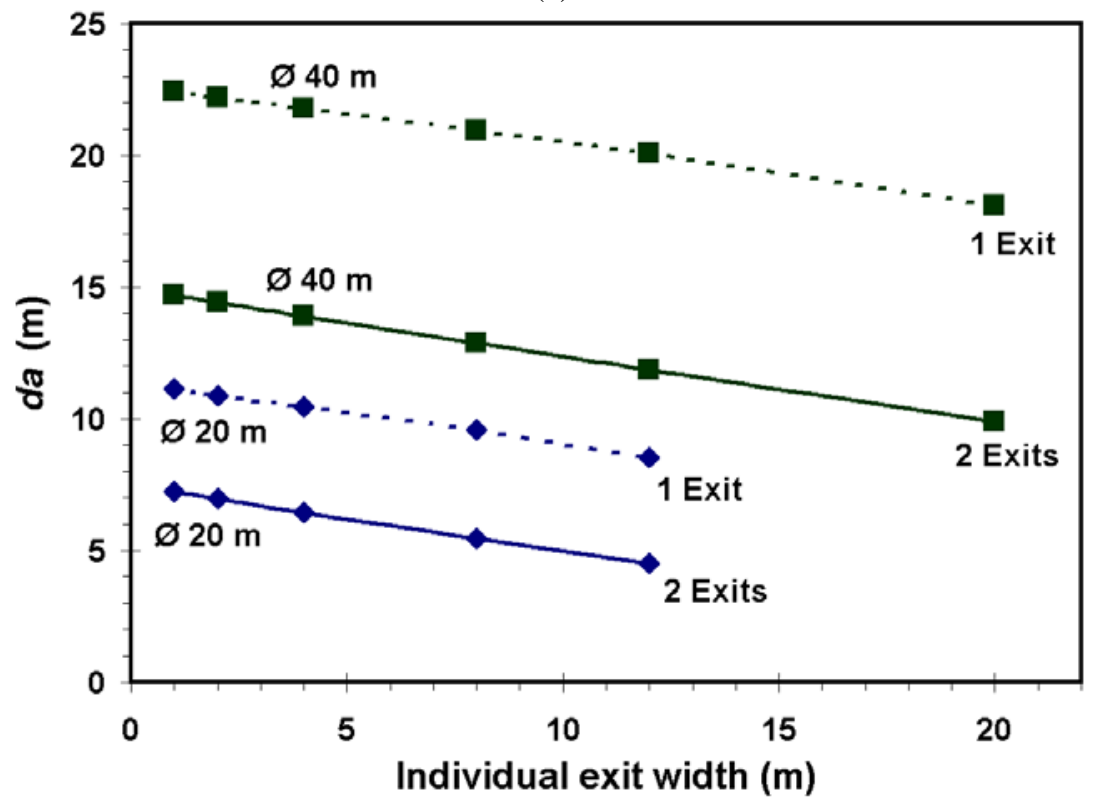

(b) 
Figure 8 - Values of $d_{a}$ for 1,2 or 4 exits with several widths, for the square environment with 10 m side (a), the square with $25 \mathrm{~m}$ side (b), and the rectangular environment (c)



(a)



(b)

Figure 9 - Values of $d_{a}$ for the square and rectangular environments, with exits of $1 \mathrm{~m}$ positioned in one side, considering 1, 2, 4, 6 and 8 exits equally distributed along this side




Figure 10 - Values of $d_{a}$ for the square and rectangular environments, with just one exit of $1,2,4$ and $8 \mathrm{~m}$ positioned at the corner, in the middle and in the centre of one side



Table 1 - Lowest and highest possible values obtained using the vS algorithm for $d_{a}$ and calculated for $d_{m}$, considering all environments

\begin{tabular}{c|c|c|c|c}
\hline \multirow{2}{*}{ Environment } & \multicolumn{2}{|c|}{$\begin{array}{c}\text { Lowest value } \\
\text { (with no wall) }\end{array}$} & \multicolumn{2}{c}{ Highest value } \\
\cline { 2 - 5 } & $\boldsymbol{d}_{\boldsymbol{a}}(\mathbf{m})$ & $\boldsymbol{d}_{\boldsymbol{m}}(\mathbf{m})$ & $\boldsymbol{d}_{\boldsymbol{a}}(\mathbf{m})$ & $\boldsymbol{d}_{\boldsymbol{m}}(\mathbf{m})$ \\
\hline Circular (Ø 20 m) & 3.4 & 10.0 & 11.3 & 20.0 \\
Circular (Ø 40 m) & 6.7 & 20.0 & 22.6 & 40.0 \\
Square (10 m side) & 1.7 & 5.0 & 7.6 & 13.9 \\
Square (25 m side) & 4.2 & 12.5 & 19.0 & 35.1 \\
Rectangle (30 m x 10 m) & 2.2 & 5.0 & 16.4 & 31.4 \\
\hline
\end{tabular}

Figure 9 presents the results for the environments with exits $1 \mathrm{~m}$ wide placed in the same side, considering 2, 4, 6 and 8 exits distributed equidistant from each other along of the side. Figure 10 presents the results for just one exit of 1, 2, 4 and $8 \mathrm{~m}$ positioned at the corner, in the middle and in the centre of one side

Thus, according to Figure 8, for both square environments, similar results were found (a reduction of about 2 to $4 \%$ with the increase in the width of a unique exit from 1 to $2 \mathrm{~m}$ ), whereas the result is around $37 \%$ smaller with two $1 \mathrm{~m}$-wide exits placed at the opposite sides. Figure 9 confirms that different exits positioned at the same side (not equally distributed along all walls) do not have the same lowering effect as the exits positioned far from each other.

For the rectangular environment, the findings are still valid, although the level of reduction in the value of $d_{a}$ is lower (Figures 8c and 10). For environments with geometries of a circle or a regular polygon, the best approximate position is easily found by simply positioning of the exits equidistantly along the walls and preferably beginning in the centre of one side.

In square and rectangular environments with only one exit, the position of the exit in the walls is relevant. Figure 10 shows that the exit located in the middle of a side provides lower values than those obtained for the exits located on intermediary positions, between the centre and the corner, or located on the corner. The results of Figure 10 are very similar to the results obtained by the calculation of the escape time in similar square environments configurations obtained using a specific software to simulate evacuation process, including some ergonomics and mental aspects (BRAGA et al., 2014). This shows that $d_{a}$ is, per si, a significant complementary parameter for safety of an environment.

Table 1 presents, for an extra comparison, the lowest and the highest possible values obtained for the $d_{a}$ and for the theoretical $d_{m}$ (maximum distance) for all environments. The lowest value is obtained considering no inner walls. The highest value is calculated considering only one exit with a width of $5 \mathrm{~cm}$ (the $r$ considered value) and, for both 
the square and the rectangular environments, positioned at the corner.

Finally, Figure 11 helps to visualise the difference in $d_{a}$ between a single exit with variable value $\left(d_{a o}\right)$ and multiple $1 \mathrm{~m}$-wide exits evenly positioned along the walls $\left(d_{a m}\right)$ for the circular (Ø $40 \mathrm{~m}$ ) environment. Figure 11a shows the evolution of $d_{a}$ as a function of the total exit width for $d_{a o}$ and for $d_{a m}$. Figure $11 \mathrm{~b}$ shows the relative difference $\left(d_{a r}\right)$ between $d_{a o}$ and $d_{a m}$, as below (Eq. 4):

$d_{a r}=\left|\frac{d_{a m}-d_{a o}}{d_{a r m}}\right| \times 100 \%$

Eq. 4
In Figure 11, for the $2 \mathrm{~m}$ total exit width, the relative difference is about 34\% in favour of multiples exits, and this relative difference increases up to about $64 \%$ for a $12 \mathrm{~m}$ total exit width in favour of multiples exits, from where the relationship starts to decrease slowly.

Figure 11 is an important finding and should be taken into account during the conception and analysis of an environment (including its project) because it shows the huge difference in safety caused by the positioning of the exits.

Figure 11 - (a) The evolution of $d_{a o}$ and $d_{a m}$ as a function of the total exit width; and (b) the relative difference $\left(d_{a r}\right)$ between $d_{a o}$ and $d_{a m}$ (for the circular $\varnothing 40 \mathrm{~m}$ )



(a)



(b) 
In addition to the compliance with legal codes, safety indexes such as the Gretener method or others (KAISER, 1980; LUNDIN, 2005; HAHNEMANN; CORRÊA; RABBANI, 2017) can also be used to determine, or at least to estimate the level of security of an environment. Obviously, safety indices, or even performance-based projects (SILVA; COELHO FILHO, 2007; SHI; SHI; REN, 2011; SPINARDI, 2016), should always be used within their limits and by professionals who fully understand them, at the risk of artificially releasing spaces that could be potentially very dangerous (CHOW, 2013; BRAGA; MOITA, 2017). The value of $d_{a}$ can be used as an element to support this kind of safety index, or introduced as a complementary index in performance-based projects. The value of $d_{a}$ can also be used to better understand, or even assist in establishing, the required parameters in fire safety codes, sometimes difficult to be understood (GISSI; RONCHI; PURSER, 2017).

In relation to the Boate Kiss accident, it can now be stated that the configuration of the exits, placed side-by-side, had almost no contribution for the reduction of the $d_{a}$ value of the environment, as opposed to the contribution that would have been obtained with displaced exits. Thus, this is a relevant issue and should be more carefully addressed in the appropriate standards.

\section{Conclusions}

A model to predict the average distance to be covered by occupants to the nearest exits $\left(d_{a}\right)$ was detailed. It could be used as a complementary parameter to indicate the safety of an environment (lower $d_{a}$ values usually tend to indicate a faster evacuation). The relationship between positioning, quantity and size of the exits and the value of $d_{a}$ was analysed for some environments.

The initial conclusions point out the importance of keeping the highest possible distance between exits in an environment, because the value of $d_{a}$ is strongly dependent on this variable and a lower $d_{a}$ can be easily obtained just by adequately positioning the exits.

For instance, in a circular 40 m-diameter environment, only two diametrically opposed $1 \mathrm{~m}$ wide exits have approximately the same effect in $d_{a}$ values that could be obtained with a large unique 25 m-wide exit. Therefore, this is a very expressive difference in favour of a careful separation between the exits.

Based on the current conclusions, engineers and architects responsible for these kinds of projects must, at least, be aware of the greatness of these values. For this reason, it is considered important that the textbooks should include this subject so that the future professional, while in the university, will be already aware of this issue. Despite the prescriptive nature of the Brazilian legislation, as seen above, an additional technical analysis of performance, as, for example, through the values of the distances to be covered to the near exit, may contribute to environmental safety. This is a point that deserves to be further discussed by the regulations.

\section{References}

ASSOCIAÇÃO BRASILEIRA DE NORMAS

TÉCNICAS. NBR 9077: saídas de emergência em edifícios. Rio de Janeiro, 2001.

BOSINA, E.; MEEDER, M.; WEIDMANN, U. Pedestrian Flows on Railway Platforms. In:

SWISS TRANSPORT RESEARCH

CONFERENCE, 17., Ascona, 2017.

Proceedings..., Ascona: EPF Lausanne, 2017.

BRAGA, H. C. et al. Simulação da Movimentação de Pessoas em Situações de Emergência: aspectos ergonômicos e computacionais com autômatos Fuzzy e sua aplicação ao projeto arquitetônico. Ambiente Construído, Porto Alegre, v. 14, p. 6177, 2014.

BRAGA, H. C.; MOITA, G. F. On the Boate Kiss Fire and the Brazilian Safety Legislation: what we can learn. Collective Dynamics, v. 2, p. 1-21, 2017.

BRAGA, H. C.; MOITA, G. F.; ALMEIDA, P. E. M. Comparação Entre os Algoritmos de Busca pela Vizinhança de Von Neumann ou de Moore para Geração do Mapa de Distâncias em um Ambiente Construído. Abakós, v. 4, p. 20-40, 2016a.

BRAGA, H. C.; MOITA, G. F.; ALMEIDA, P. E. M. High Quality Pathfinder Algorithm to be Used to Find the Best Route to the Nearest Exit of an Environment. In: INTERNATIONAL CONFERENCE ON PEDESTRIAN AND EVACUATION DYNAMICS, 8., Hefei, 2016. Proceedings... Hefei: University of Science and Technology of China, 2016b.

BRAGA, H. C.; MOITA, G. F.; ALMEIDA, P. E. M. Mapas de Distâncias Para a Segurança Contra Incêndio em Edifícios de Interesse Social. PARC: Pesquisa em Arquitetura e Construção, v. 8, p. 32-45, 2017.

CHOW, W. Experience on Implementing Performance-Based Design in Hong Kong. Procedia Engineering, v. 62, p. 28-35, 2013. 
CLARET, A. M.; MATTEDI, D. L. Estudo da Prescritividade das Normas Brasileiras de Segurança Contra Incêndio. Rem: Revista Escola de Minas, v. 64, n. 3, p. 265-271, 2011.

DAAMEN, W.; HOOGENDOORN, S. P. Emergency Door Capacity: influence of door width, population composition and stress level. Fire Technology, v. 48, p. 55-71, 2012.

DORAZIO, M. et al. Design and Experimental Evaluation of an Interactive System for PreMovement Time Reduction in Case of Fire. Automation in Construction, v. 52, p. 16-28, 2015.

DUVAL, R. F. NFPA Case Study: nightclub fires. NFPA: Quincy, 2006.

GISSI, E.; RONCHI, E.; PURSER, D. A.

Transparency vs Magic Numbers: the development of stair design requirements in the Italian fire safety code. Fire Safety Journal, v. 91, p. 882891, 2017.

GOLDSTONE, R.; ROBERTS, M. E. SelfOrganized Trail Systems in Groups of Human. Complexity, v. 11, p. 43-50, 2006.

HAHNEMANN, A.; CORRÊA, C.; RABBANI, E. Avaliação de Segurança Contra Incêndio: método alternativo aplicado a edificações brasileiras. Revista Alconpat, v. 7, n. 2, p. 186-199, 2017.

KAISER, J. Experiences of the Gretener Method. Fire Safety Journal, v. 2, p. 213-222, 1980.

KOBES, M. et al. Building Safety and Human Behavior in Fire: a literature review. Fire Safety Journal, v. 45, p. 1-11, 2010.

KULIGOWSKI, E. D. et al. Stair Evacuation of People with Mobility Impairments. Fire and Materials, v. 39, p. 371-384, 2015.

LOW, D. J. Statistical Physics: following the crowd. Nature, v. 47, p. 465-466, 2000.

LUJAK, M.; OSSOWSKI, S. Evacuation Route Optimization Architecture Considering Human Factor. AI Communications, v. 30, n. 1, p. 53-66, 2017.

LUNDIN, J. Development of a Framework for Quality Assurance of Performance-Based Fire Safety Designs. Journal of Fire Protection Engineering, v. 15, p. 19-42, 2005.

MOUSSAÏD, M.; HELBING, D.; THERAULAZ, G. How Simple Rules Determine Pedestrian Behavior and Crowd Disasters PNAS, v. 108, p. 6884-6888, 2011.
PAN, X. et al. Multi-Agent Based Framework for the Simulation of Human and Social Behaviors During Emergency Evacuations. AI and Society, v. 22, p. 113-132, 2007.

PELECHANO, N.; ALLBECK, J.; BADLER, N. Virtual Crowds: methods, simulation, and control. Williston: Morgan \& Claypool Publishers, 2008.

ROGSCH, C. The Influence of Moore and vonNeumann Neighbourhood on the Dynamics of Pedestrian Movement. In: KNOOP, V.;

DAAMEN, W. Traffic and Granular Flow '15. New York: Springer, 2016.

RONCHI, E.; NILSSON, D. Fire Evacuation in High-Rise Buildings: a review of human behaviour and modelling research. Fire Science Reviews, v. 2, n. 7, 2013.

SHI, J.; SHI, W.; REN, A. An Integrated Model For the Fire Safety of Large Space Buildings. Advances in Structural Engineering, v. 14, p. 763-776, 2011.

SILVA FILHO, L. C. P. et al. Análise do Sinistro da Boate Kiss em Santa Maria, RS. Porto Alegre: CREA-RS, 2013.

SILVA, V. P.; COELHO FILHO, H. S. Índice de Segurança Contra Incêndio para Edificações.

Ambiente Construído, Porto Alegre, v. 7, n. 4, p. 103-121, out./dez. 2007.

SOLTANI, A. R. et al. Path Planning in Construction Sites: performance evaluation of the Dijkstra, A*, and GA search algorithms.

Advanced Engineering Informatics, v. 16, n. 4, p. 291-303, 2002.

SPINARDI, G. Fire Safety Regulation: prescription, performance, and professionalism. Fire Safety Journal, v. 80, p. 83-88, 2016.

TAVARES, R. M. An Analysis of the Fire Safety Codes in Brazil: is the performance-based approach the best practice? Fire Safety Journal, v. 44, p. 749-755, 2009.

TAVARES, R. M. Design For Horizontal Escape in Buildings: the use of the relative distance between exits as an alternative approach to the maximum travel distance. Safety Science, v. 48, p. 1242-1247, 2010.

THOMPSON, A. M. The Navigation System of the JPL Robot. Jet Propulsion Laboratory-NASA, 1977.

THOMPSON, P. A.; MARCHANT, E. W. A Computer Model For the Evacuation of Large Building Populations. Fire Safety Journal, v. 24, n. 2, p. 131-148, 1995. 
XIE, Q. et al. The Optimization for Location of Building Evacuation Exits Considering the Uncertainty of Occupant Density Using Polynomial Chaos Expansion and Genetic Algorithm. Procedia Engineering, v. 211, p. 818829, 2018.

XUE, S. et al. Pedestrian Evacuation in View and Hearing Limited Condition: the impact of communication and memory. Physics Letters A, v. 380, n. 38, p. 3029-3035, 2016.

\section{Acknowledgments}

The authors would like to thanks CNPq and CAPES for the financial support received during this work.

\section{Henrique Costa Braga}

Programa de Pós-graduação em Modelagem Matemática e Computacional | Centro Federal de Educação Tecnológica de Minas Gerais Av. Amazonas 7675, Nova Gameleira | Belo Horizonte - MG - Brasil | CEP 30510-000 | Tel.: (31) 3319-6807 | E-mail:

bragaseg@yahoo.com.br

\section{Gray Farias Moita}

Programa de Pós-graduação em Modelagem Matemática e Computacional | Centro Federal de Educação Tecnológica de Minas Gerais | E-mail: gray@dppg.cefetmg.br

\section{Paulo Eduardo Maciel de Almeida}

Programa de Pós-graduação em Modelagem Matemática e Computacional | Centro Federal de Educação Tecnológica de Minas Gerais | E-mail: pema@lsi.cefetmg.br

\section{Revista Ambiente Construído}

Associação Nacional de Tecnologia do Ambiente Construído

Av. Osvaldo Aranha, 99 - 30 andar, Centro

Porto Alegre - RS - Brasil

CEP $90035-190$

Telefone: +55 (51) 3308-4084

Fax: +55 (51) 3308-4054

www. seer. ufrgs. br/ ambienteconstruido

E-mail: ambienteconstruido@ufrgs.br

(c) (i) This is an open-access article distributed under the terms of the Creative Commons Attribution License. 